\title{
Editorial
}

\section{Helping from the nursing perspective}

\author{
Sylva Bártlová * \\ University of South Bohemia in České Budějovice, Faculty of Health and Social Sciences, Institute of Nursing, Midwifery \\ and Emergency Care, České Budějovice, Czech Republic
}

\begin{abstract}
"Helping" is a general term with a number of variations, meanings and goals that lead to its implementation. Helping can be described as an "active participation in solving a particular life situation with a particular (specific) goal resulting from a threat or need. It is a collection of activities through which revealed shortcomings are compensated, i.e. individuals are mobilized and helped to secure for themselves social and psychological stability and social independence and, as a result, to increase the quality of their lives" [1]. Helping means the help that one person or a group of persons are provided with by another person. This help may be financial, material or psychological [2]. The motive for such an activity is the need to do others good, to expend some energy, to pass over something from the personal abundance and, as a result, to remove or relieve the unfavourable situation in which the other person is found. Helping professions play an important role in these problems.
\end{abstract}

There are a number of helping professions. Frankl [3] says that there are people who have abilities and skills to help others and choose this profession as a mission. They include advisors, psychologists, priests, psychotherapists and social workers. They are expected to help people to manage their social and emotional problems. Frankl [3] describes them as people "helping at the first level". People "helping at the second level" are professionals specialized in another profession but cannot, at the same time, avoid providing people in a critical situation with help. They include, for example, policemen, teachers and healthcare professionals [3].

Cowen [4] complements Frankl [3] by speaking about people "helping at the third level". They include such professionals as managers, supervisors and even barbers, hairdressers and bartenders, etc. They also meet people in a crisis. They can listen attentively to them talk, express support, give them advice and generally help them to manage their problems. The person "helping at the fourth level" is anybody trying to help a relative, friend, somebody they know or even a stranger to deal with a problem.

Carkhuff and Pierce [5] divide the helping persons into functional (those who have skills needed for helping), and non-functional (those who lack these skills). The best helping professionals are people who continuously refresh their practical knowledge and abilities to help, particularly by means of feedback from their clients.

The professional helpers in healthcare include doctors, nurses, other non-medical professionals and social workers, i.e. those whose complete orientation, their profession, is focused on various ways of helping others. Helping professions are ranked among the professions that need skills and knowledge about the way of helping. The psychological and social aspects of healthcare professions, particularly the nursing profession, which is one of the helping professions, demand interdisciplinary nursing education that ensures healthcare professionals understand their specialty as a multicultural and transdisciplinary specialty. This positively influences the approach to patients and enables the individualization of nursing care and a complex approach to a patient.

The nursing profession is one of helping professions focused on giving assistance to individuals, families and communities in achieving, maintaining and recovering optimum health and functioning. V. Henderson [6], who significantly influenced nursing in the middle of the previous century, saw the basic nursing function as "helping healthy or ill individuals to perform activities

\footnotetext{
* Author for correspondence: Assoc. Prof. Sylva Bártlová, Ph.D., University of South Bohemia in České Budějovice, Faculty of Health and Social Sciences, Institute of Nursing, Midwifery and Emergency Care, U Výstaviště 26, 37005 České Budějovice, Czech Republic; e-mail: bartlova@zsf.jcu.cz; http://dx.doi.org/10.1016/j.kontakt.2017.11.002
} 
related to health and health protection in situations during which they are unable to do so themselves and do not have the necessary strength and will or knowledge".

The World Health Organization (WHO) $[7,8]$ stated that the healthcare systems and healthcare service had been focused on biomedical aspects for a long time: they had been focused on diseases and improvement and the utilization of technologies. At present, greater attention has to be paid to the needs of patients, their families, communities and society as a whole. As early as 1960, a patient-centred approach was defended saying that the basic building block of nursing care was an individualized approach both to the patient and to the care the patient was provided with [9]. The concept of individualized care has decisive importance for the delivery of healthcare. The basic attribute of nursing care is to treat patients as individual beings with all their specific peculiarities. In professional nursing literature, individualized care is repeatedly described as a basic component of nursing and as a basic principle in clinical practice. Nurses' moral awareness is an expression of their respect for the individuality of each patient [10]. Individualized care is connected with the required quality of professional nursing care and patient rights.

However, there are a number of objective obstacles that can complicate person-centred care, namely: the shortage of healthcare staff, both medical and nursing staff; preference of evidence-based medicine and nursing; emphasis placed on recommended procedures (guidelines), development and maintenance of nursing care standards; differences in opinions over what is the substance of the individual approach to patients from the medical and nursing perspective. In nursing management, this frequently concerns the overestimation of nursing records. Help should be provided in an atmosphere of trust and human understanding. Problem situations cause uncertainty, worries and fear. Therefore, helping professionals should arouse trust, safety and peace. This, naturally, demands time for listening and talking.

\section{REFERENCES}

[1] Kraus B. Základy sociální pedagogiky. Praha: Portál; 2008.

[2] Hopson B. Counselling and helping. In: Herbert M. Psychology for social workers (Psychology for professional groups). 2nd ed. London: The British Psychological Society and Macmillan publishers Ltd; 1986, pp. 172-202.

[3] Frankl VE. The unheard cry for meaning: psychotherapy and humanism. New York: Simon and Schuster; 1978, pp. 35-40.

[4] Cowen EL. Help is where you find it: four informal helping groups. American Psychologist 1982;37(4): 385-95.

[5] Carkhuff RR, Pierce R. The art of helping III, trainers guide. Amherst: Human Resource Development Press; 1977, p. 59.

[6] Matulník J. Přeměny a problémy profese zdravotní sestry. Sociológia 1990;22(2):151-62.

[7] World Health Organization. People-centred health care: a policy framework. Manila: World Health Organization; 2007.

[8] World Health Organization. WHO global strategy on people-centred and integrated health services: interim report. Geneva: World Health Organization; 2015.

[9] Van Servellen G. Nurses' perceptions of individualized care in nursing practice. Western Journal of Nursing Research 1988;13(3):291-306.

[10] Suhonen R, Valimaki M, Leino-Kilpi H. Individualised care from patients', nurses' and relatives' perspective: a review of the literature. International Journal of Nursing Studies 2002;39(6):645-54. 